\title{
On the Eastern Turkic Grammatical Characteristics in the Mirajname Text Found in the Kitab of Ibn Abraham Koricki
}

DOI: http://dx.doi.org/10.12775/LC.2020.007

\begin{abstract}
The manuscripts of the Lithuanian Tatars are comprised of religious works written in the Arabic script like Kitab, Tafsir, Hamail, Tajvid. These manuscripts preserved texts concerning such languages as Chagatai Turkic, Old Anatolian Turkish, Belarusian and Polish. Especially the type of manuscripts named Kitab is important as it bears relation to the Turkish language, because in the type of Kitab, Slavic translations are found between the lines of some Turkish texts. One of the texts found within the type of Kitab is the text of the mirajname that belongs to the period of the Old Anatolian Turkish. Since XIV ${ }^{\text {th }}$ century numerous examples of mirajname have occurred in Turkish literature, however its appearance in the manuscripts of Lithuanian Tatars is a curious case.

In this article the Eastern Turkic grammatical features in the mirajname text found in the Kitab of Ibn Abraham Koricki that belongs to the period of the Old Anatolian Turkish shall be analyzed and generally the reasons of the appearance of the Eastern Turkic forms of words and suffixes in the mirajname text written according to the grammatical characteristics of Western Turkic shall be discussed.
\end{abstract}

Key words: Lithuanian Tatars, Kitab of Ibn Abraham Koricki, Mirajname, Old Anatolian Turkish, Eastern Turkic

* Ph.D., Associate Professor at the Department of Turkish Language and Literature, Faculty of Arts and Sciences, University of Canakkale Onsekiz Mart, Turkey. His research interests include historical and contemporary Turkic languages, as well as Lithuanian Tatars.

E-mail: hdurgut@comu.edu.tr | ORCID: 0000-0001-7237-3381. 


\title{
O wschodnio-tureckich cechach gramatycznych w tekście Miradż znalezionym w Kitabie Ibn Abrahama Koryckiego
}

\begin{abstract}
Streszczenie. Rękopisy Tatarów litewskich obejmują na ogół teksty religijne zapisane alfabetem arabskim, takie jak kitaby, tefsiry, hamaiły i tedżwidy. Są one świadectwem współistnienia kilku języków: czagatajskiego, staroanatolijskiego, białoruskiego i polskiego. Zabytki określane jako kitaby są szczególnie ważne ze względu na ich związek z językiem należącym do grupy języków turkijskich. $\mathrm{W}$ tekstach tych pojawiają się fragmenty interlinearnego przekładu z języka tureckiego. Jednym z zabytków reprezentujących tę grupę jest Miradż. Pochodzi on z okresu staroanatolijskiego języka tureckiego. W literaturze tureckiej od XIV w. pojawia się wiele przykładów legendy Miradż, jednak jej obecność w rękopisach Tatarów litewskich jest niezwykle interesująca.

W pracy przeanalizowano zatem wschodnioturkijskie cechy gramatyczne tekstu Miradż zawartego w Kitabie Ibn Abrahama Koryckiego reprezentującego okres staroanatolijski w rozwoju języka tureckiego. Omówiono też przyczyny pojawienia się wschodnioturkijskich form i sufiksów w tekście Miradż, który zapisano zgodnie z gramatycznymi wymogami jednego z języków zachodnioturkijskich.
\end{abstract}

Słowa kluczowe: Tatarzy litewscy, Kitab Ibn Abrahama Koryckiego, Miradż, język turecki okresu staroanatolijskiego, język wschodnioturkijski

\section{Introduction}

atar communities which had started to settle in the Grand Duchy of Lithuania approximately 620 years ago have still maintained their existence by protecting their religious beliefs and identities in the countries such as Lithuania, Poland and Belarus. The first Tatar groups who escaped from the disorders in Golden Horde in XIV ${ }^{\text {th }}$ century settled in Lithuania lands under the auspices of Witold, Grand Duchy of Lithuania. After the first migration, the migrations of Tatars to this region continued in the following centuries. The term of the Lithuanian Tatars has started to be used since XIX ${ }^{\text {th }}$ century for Tatar ethnonymy in this region which used to be referred by terms such as Grand Duchy of Lithuania Tatars, Radzivil Tatars, Kazak Tatars, Lipka in the historical resources between XV $V^{\text {th }}$ and XVIII ${ }^{\text {th }}$ centuries (Miškiniene 2015: 51). In recent studies, the terms such as Lithuanian Tatars, Poland Tatars, Belarussian Tatars, Poland-Lithuanian Tatars and Belarussian-Poland-Lithuanian Tatars are used for referring to this Tatar community who lives in Poland, Lithuania and Belarus at the present time. The term of the Lithuanian Tatars that we used in this study also covers the Tatars today who live in Belarus and Poland as well as in Lithuania.

The Tatars who settled in the lands of Grand Duchy of Lithuania had begun to forget their mother tongue due to various reasons since XVI century. Some of the reasons 
of forgetting their mother tongue by Tatars are settling in the region very far away their homeland, the limited number of population at the time of their first settlement, the differences in their social status, being allowed to get married to Christian women, not having a common worship language. Tatar communities who came to Grand Duchy of Lithuania were not homogeneous. Most of Tatars who came in $\mathrm{XIV}^{\text {th }}$ century were single warriors. These Tatar men were allowed to get married to Christian women provided that they would not force women to proselytize (Orhonlu 1971: 60). In our opinion, this is the most significant reason why Lithuanian Tatars forgot their mother tongue. This is because the children who were born in these marriages with foreign women primarily learned their "mother” tongue. There were also married Tatars who settled in the lands of Lithuania and Poland after the first settlement period. Moreover, some of Tatars went to Crimea or Ottoman lands and returned after they got married to Muslim women there. The mother tongue loss was slower in the children who were born in the marriages with Tatar and Muslim women. However, the mother tongue loss continued in the lands of Lithuania-Poland since Tatar language was not a communicative language, so other languages which were spoken here substituted Tatar language.

\section{Manuscripts of the Lithuanian Tatars}

The Lithuanian Tatars have still been able to maintain their identities and religions under favor of the privileges given to them in the region where they settled and since they did not suffer oppression from the society and their administrators. The Tatars living in the lands of Lithuania - Poland needed for translation of Islamic texts into Slavic languages in order to fulfill their religious needs when they forgot their mother tongue. Along with the translation of religious texts such as the interpretations of Quran, prayer and catechism books first into Belarussian and then Polish, the tradition of manuscript of the Lithuanian Tatars was formed (Miškinienè 2011: 227). It is also very interesting that the alphabet used in these manuscripts is Arabic Alphabet. Therefore, the Arabic Alphabet had started to be used for writing Slavic languages which have various phonemes. The manuscripts of the Lithuanian Tatars consists of religious texts such as Kitab, Tafsir, Hamail, Tajvid written in Arabic alphabet. In particular, the manuscripts in Kitab and Hamail types are very significant since they concern Turkish language. This is because there are prayers and religious stories which were written in Turkish language and their translations into Belarussian or Polish as well as religious texts in Arabic language. The most attractive one among the manuscripts of the Lithuanian Tatars is the genre named as Kitab. Although kitäb, an Arabic origined word, literally refers to written paper sheets brought together, it gained a special meaning in the language of the Lithuanian Tatars. This is because there are rich and various parts in these kitabs such as explanatory and instructive information concerning to basics of Islam, some surahs and hadiths, some texts concerning to classical literature of Islamic period, the stories concerning to the life of Prophet Muhammad, his struggle and death, the texts concerning to other prophets, descriptions of religious ceremonies and the information concerning to traditions and customs of local society who is not Muslim. There were problems such as spelling, wording, correction errors in these texts which were written with Arabic letters in the 
languages such as Belarussian, Polish, Arabic and Turkish since they were replicated several times. However, these problems did not cause the loss of their value (Miškiniene 2015: 37). Even these Kitabs gained the qualification of a sacred book for Lithuanian Tatars. The studies of review the manuscripts of the Lithuanian Tatars which was started in XIX ${ }^{\text {th }}$ century is referred as Kitabistics recently. The surahs and hadiths in these Kitabs were written in Arabic language while some prayers and religious texts were written in Turkish language with Slavic interlinear translation. Other parts were directly written in Slavic languages which were used in that region.

One of religious texts in Kitabs is mirajname. Until 2011, 181 manuscripts of the Lithuanian Tatars were found and 27 of them belong to type of Kitab (Miškiniene 2011: 227). There are also mirajname text in 10 of these Kitabs. In 5 of these 10 manuscripts having mirajname, the mirajname text is in Turkish language and given along with its interlinear translation into Belarussian language. In other 5 manuscripts, the original Turkish text of mirajname is not given and there is only its Belarussian translation (Durgut 2013: 337). The manuscripts in the type of Kitab which have mirajname text in Turkish language are as follows: Kitab of Ivan Luckevich (early XVIII ${ }^{\text {th }}$ century), Kitab of London (mid-XIX ${ }^{\text {th }}$ century), Kitab of Ibrahim Hasenevich (first half of the XIX ${ }^{\text {th }}$ century), Kitab of Ibn Abraham Koricki (mid-XIX ${ }^{\text {th }}$ century), Kitab of Abrahim Hasenevich (second half of the XIX ${ }^{\text {th }}$ century) (Miškinienè et al. 2005: 39-58; Akiner 2009: 81).

\section{Kitab of Ibn Abraham Koricki and Mirajname}

Kitab of Ibn Abraham Koricki registered in Vilnius University Library under the number of F3-391 is a manuscript which was written mid-XIX ${ }^{\text {th }}$ century with naskh script. Along with that most of texts are in Belarussian language, there are also texts in Polish, Arabic and Turkish language. We understand that the person who copied the script was a person named Ibn Abraham Koricki based on the inscription of „ибн абрагам карицки писа kита6" in $360^{\text {th }}$ page at the end of script. There is no information about his life in the sources. Based on the content of manuscript, we may assume that Ibn Abraham Koricki knows Belarusian and Arabic well but does not know Turkish well. When we review the content of manuscript, we may see a genealogy in first 11 pages at which there are names of some prophets and famous persons. The manuscript starting with Fatihah surah continues along with Taha and Yasin surahs. There are various religious and non-religious subjects in the book which is a very voluminous work. A few examples of these primary subjects are as follows: the story of prophet Ibrahim and Nimrud, the story of Pehlûl Divâne, the story of Ali and old man, Adam and Eve, the prophet Noah and Noah's Ark, the story of Uzair, the story of prophet Suleiman, the astronomical calculations concerning to the position of Sun and Moon, the texts concerning to prayer and its significance, texts concerning to significance of reading Quran, and texts concerning the beverages which make drunk.

In the first instance, Antonowicz mentioned about Kitab of Ibn Abraham Koricki. In his monography named Belarussian Texts and Their Graphic-Spelling System Written with Arabic Letters which was published in 1968, Antonowicz introduced twenty three manuscripts with graphic and spelling features and also the information concerning to Kitab 
of Ibn Abraham Koricki is given in this study (Antonowicz 1968: 57-62). The detailed information concerning to Kitab of Ibn Abraham Koricki is given in the study named Catalogue of Manuscripts in Arabic Letters of the Lithuanian Tatars which was issued by G. Miškinienè, S. Namavičiute and J. Pokrovskaja in 2005 and the parts of the Kitab were introduced in the form of titles (Miškinienè et al. 2005: 58-61). With her three articles, G. Miškiniene is the first researcher who made detailed studies concerning to the mirajname in Kitab of Ibn Abraham Koricki (see, Miškinienè 2013; 2014a; 2014b). In addition, in 2016, the text of Turkish mirajname in Kitab of Abraham Koricki was analyzed in a publication of Hüseyin Durgut. However, in the study mentioned, Eastern Turkic grammatical characteristics in the mirajname text were not examined in detail (see: Durgut 2016).

The mirajname text in Turkish is located between $249^{\text {th }}$ and $305^{\text {th }}$ pages of this manuscript. There are interlinear translations of each couplet into Belarussian language. There are some wrong translated or approximate expressions used parts in these translations. The mirajname is in the type of masnavi. As in other masnavis, it starts with praise to Allah. It continues with the prophet Muhammad's ascension referencing the narrative of Ibn Abbas. Then, it mentiones the meeting of prophet Muhammad with Gabriel and heralding his ascension to Muhammad by Gabriel. Burak which was the vehicle used by prophet Muhammad during this journey is described in detail. There are attractive depictions and themes in mirajname. The names of some of seven sky layers and what they were made from are told. The meeting of prophet Muhammad with Allah is described in detail. The broad depictions of some concepts and objects such as heaven, hell, houri, angels, Tuba tree, Salsabil river are given. The subjects such as the prophet Muhammad's meeting with other prophets and instructing them to perform salaat are also covered (Durgut 2013: 338-339). At the end of the text, the return of prophet Muhammad to Mecca and telling this miracle to caliph Abu Bakr, caliph Omar, caliph Osman and caliph Ali and their expression to believe in this are told. Based on the inscription of "hacı mahmud didi uşbu me'rac1 [Hadji Mahmud told this mirajname]" located at the ends of text, we understand that the author of this mirajname is a person named $\mathrm{Hacl}$ Mahmud. In the researches we made, we could not detect a mirajname author named $\mathrm{Hacl}$ Mahmud. Moreover, the name of author is not also stated in two mirajnames written in the field of Anatolia which we consider as reference to miraj text we have.

It is not known when and how a mirajname text written in the field of Anatolia was transferred to manuscripts of the Lithuanian Tatars. Several texts were written about the subject of miraj in the fields of both Eastern and Western Turkish literature. The text that we review here is one of mirajname texts originated from Anatolian field. As a result of researches we made, the mirajname in Kitab of Ibn Abraham Koricki shows a great similarities with two mirajname texts written in the field of Anatolia. One of these two texts is registered within the manuscripts numbered 4038 and 4039 in Library of Turkish Language and Literature of Istanbul University. This mirajname was reviewed by Hayati Develi in detail and published along with its facsimile (Develi 1998: 81-228). Other mirajname is registered in Topkapı Palace Museum, Revan Library under the number of 989. A post-graduate study about this mirajname was carried out by Sema Çimen and the facsimile of this text was added to the end of thesis (Çimen 2010). We think that Turkish mirajname in Kitab of Ibn Abraham Koricki and other manuscripts of the Lithuanian Tatars is based on the same source of these two mirajnames written in Old Anatolian Turkish. Therefore, in this study, 
the suffixes and words having the properties of Eastern Turkic which are found in the mirajname in Kitab of Ibn Abraham Koricki were compared with the suffixes and words in these two mirajnames written in the field of Anatolia.

\section{The Characteristics of Eastern Turkic in the Mirajname in Kitab of Ibn Abraham Koricki}

Primarily, we would like to state that the grammatical features of Western Turkic, in other words Oghuz Turkic appear in most parts of the mirajname in Kitab of Ibn Abraham Koricki because it is a text belonging to Old Anatolian Turkish. However, the grammatical features of Eastern Turkic also appear in some parts of the text. Here, the term of Eastern Turkic is refered to dialects of Turkic language which were used in mid periods of historical Turkic languages except for Oghuz Turkic. As known, the Turkish language continued in three different literary languages as Kharezm Turkic in east, Kipchak Turkic in north and Oghuz Turkic in west between XIIIrd and XIV ${ }^{\text {th }}$ centuries. The Chagatai Turkic substituted the Kharezm Turkic since $\mathrm{XV}^{\text {th }}$ century. The Turkic communities in west had continued to use Oghuz Turkic as literary language while the Turkic communities in east had continued to use Chagatai Turkic as literary language from $\mathrm{XV}^{\text {th }}$ century to $\mathrm{XX}^{\text {th }}$ century.

\section{The change of $b->m$ - at the beginning of words}

The change of $b$ sound at the beginning of words, starting with $b$ sound and having $n$ or $\tilde{n}$ sounds, to $m$ sound due to regressive assimilation has been a common characteristic Eastern Turkic since Old Uyghur Turkic period. To illustrate, this sound change occurs in the words such as ben > men, biñ $>$ miñ, beñiz > meñiz, bin- > min-. This phonetic change is a characteristic feature of Karakhanid, Kharezm, Kipchak and Chagatai Turkic literary languages. The Western Turkic originated from Oghuz Turkic does generally not have this phonetic change. However, this change also occurrs in Azerbaijan Turkic and Turkmen Turkic which are influenced by Chagatai Turkic literary language. Yet, this change does not arise in Old Anatolian Turkish and Ottoman Turkish which are historical Turkic dialects, and Turkey Turkish and Gagauz Turkish which are contemporary Turkic dialects. Therefore, the words given above as examples are seen with $b$ forms in the Old Anatolian Turkish. Although the $b$ forms of these kinds of words are very common in the mirajname in Kitab of Ibn Abraham Koricki, supposed that it was replicated from an Old Anatolian Turkish period mirajname, we also come across with $m$ forms of these words in the text rarely. Thus, there are dual use of some words in the text. Some words from the text are given below as examples.

ben $>$ men: While the first person singular pronoun was used in the form of ben for 26 times in the text we reviewed, it was used as men only in a couplet. 
bindüm burāk üstine ha giderem

subḥ yakın men mekkiye irerem (AK, 498) ${ }^{1}$.

The word of men in this couplet is found in the form of ben in other mirajname texts belonging to Old Anatolian Turkish.

bindüm burāk üstine ha sürerem

subh yakin be n mekkeye irerem (IU, 491) $)^{2}$.

$b$ in - > men - : While this verb was used in the form of $b$ for 15 times in total as in the form of bin-for 11 times and ben-for 4 times, it was used as $m$ in the form of $m e n$-for 1 time.

eytdi sözümi diñlag̀ıl yā cebrā'il

menmedi [mi] baña ibrähim halil (AK, 70)

The verb of men-in this couplet was used in the form of bin-in mirajname texts belonging to Old Anatolian Turkish.

eyitti sözüm işitgil yā cebrā'il

binmedi mi baña ibrähim halil (IU, 69)

be $\tilde{n} z e->m e \tilde{n} z e-$, miñze-: While the verb of beñze-in the text we reviewed was used in the form of beñze-for 5 times, it was used as meñze-for 1 time and miñze-for 1 time.

geçdüm andan yene gördüm bir ķoça

saçı sakalı me ñzer kamuça (AK, 333)

gögsi at adam mi $\tilde{n} z$ er yüzi

cevher gevherdür eki gözi (AK, 59)

The verbs of meñze- and miñze- in these couplets were used as beñze- in the mirajname texts in the field of Anatolia.

geçtüm andan dahı gördüm bir koca

saçı sakalı be ñzerdi ag̉aca (IU, 325)

gevdesi at ädeme be ñzer yüzi

yıldırım gibi şakır iki gözi (IU, 58)

As it seen in the examples, the change of $b->m$ - is not a common feature in the mirajname in Kitab of Ibn Abraham Koricki. There are certainly $b$ forms of these $m$ forms which are rarely seen in the text.

\section{The Use of Genitive Suffix in the Form of $+n I \tilde{n} /+n U \tilde{n}$}

The genitive suffix is used in the form of $+n I \tilde{n} /+n U \tilde{n}$ for the words ending with vowels while it is used in the form of $+I \tilde{n} /+U \tilde{n}$ for the words ending with consonant in Western Turkic. On the other hand, it is used as only $+n I \tilde{n} /+n U \tilde{n}$ suffix for the words ending with both vowels and consonants in Eastern Turkic, specifically starting from Chagatai Turkic. In the text we reviewed, the genitive suffix was generally used as $+n I \tilde{n} /+n U \tilde{n}$ and $+I \tilde{n} /+U \tilde{n}$

1 AK: The text of mirajname in Kitab of Ibn Abraham Koricki, see Durgut (2016: 178-234).

2 IU: The text of mirajname in Library of Turkish Language and Literature of Istanbul University, see Develi (1998: 206-228). 
according to the rule of Western Turkic. However, it is also seen in some couplets of the mirajname that this suffix was added in the form of $+n I \tilde{n} /+n U \tilde{n}$ to some words ending with consonant as it is in Eastern Turkic. The couplets at which this characteristic of Eastern Turkic were determined for 5 times totally in mirajname in Kitab of Ibn Abraham Koricki are as follows:

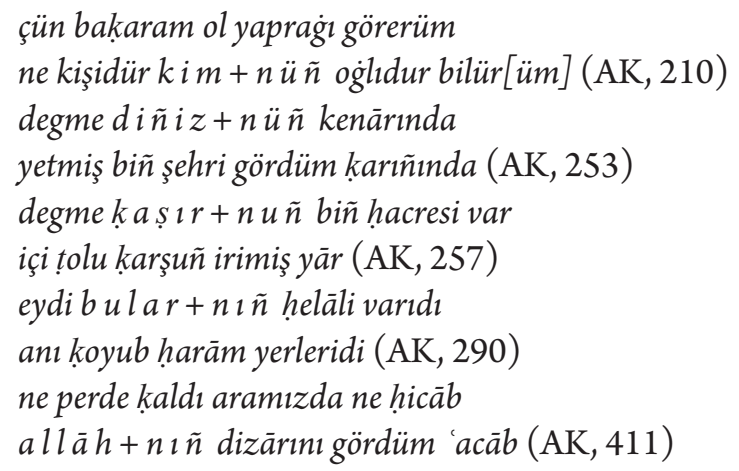

The words of kim+nün, diñiz+nüñ kașir+nuñ, bular+niñ, allāh+niñ given in the cou-

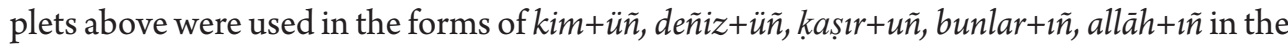
mirajname texts belonging to Old Anatolian Turkish period.

\section{The Use of Ablative Suffix in the Form of +DIn}

While the ablative suffix is used as wide vowel in the form of $+D A n$ in Western Turkic, it is always used in the form of $+D I n$ as narrow vowel in Eastern Turkic. In the text we reviewed, this suffix was generally used in its form in Western Turkic. However, its narrow vowel form in Eastern Turkic was used in only one couplet.

geçdüm and in ogradum bir 'avrata

'acabā kaldum nıçı ol șūrete (AK, 91)

This andin form which is the ablative case of $o l$ demonstrative pronoun was always used in the form of andan in other parts of the text. Furthermore, the word of andin in this couplet was used in the form of andan in mirajname texts in the field of Anatolia.

\section{The Disuse of Pronimal $n$}

In Turkic languages, pronimal $n$ is used when case suffixes or plural suffix are added to pronouns ending with vowel generally. This usage is not a characteristic for Eastern Turkic. In this text we reviewed, we came across the feature of disuse of pronimal $n$, as it is in Eastern Turkic, only on the demonstrative pronoun of $b u$ in seven couplets in total.

ben eydüm yā cebrāil kimdür bu lar

cebrāil eydür ümmetin olmak diler (AK, 88)

ben eytdüm bu la r kim dururlar

kim helāli koyub harāmı yerler (AK, 289)

Beside these two examples, bular which is the plural form of $b u$ is used in five more couplets $\left(90,134,262,274\right.$ and $290^{\text {th }}$ couplets). The form of bunlar which is the Western 
Turkic form of bular is seen in this text for 11 times. All of these examples of bular form in mirajname in Kitab of Ibn Abraham Koricki were used as bunlar form in the mirajname texts of the field of Anatolia.

\section{The Use of Birle Conjunction}

The conjunction of birle which is widely used in Eastern Turkic is not used in Western Turkic. Instead of this, the conjunctions of ile and bile are widely used in Western Turkic. While the conjunction of bile was used for 4 times in the text we reviewed, the conjunction of birle was used for 1 time.

bir ferişte geldi kapu'ı oçar

yetmiş biñ ferişte b irle șaçu șaçar (AK, 145)

birle conjuction which was used in mirajname in Kitab of Ibn Abraham Koricki was used as bile form in the mirajname texts of the field of Anatolia.

\section{Conclusion}

Kitabs which contain texts in Turkish is one of the very significant works for Turkish language among the manuscripts of the Lithuanian Tatars. Since the text of Turkish mirajname which is found in some of Kitabs is very voluminous, it allows for making language review by using this text. The mirajname text in Kitab of Ibn Abraham Koricki that is reviewed in this study is almost identical to mirajname texts in other manuscripts of the Lithuanian Tatars. Therefore, the features of Eastern Turkic that appear in the text are also seen in other mirajname texts in Kitabs of the Lithuanian Tatars. In this study, it is noticed that there are some grammatical features belonging to Eastern Turkic in the mirajname text of Kitab of Ibn Abraham Koricki. However, this limited number of grammatical features of Eastern Turkic are not seen in the mirajname texts in the field of Anatolia which are the origins of the mirajname we reviewed. According to our estimation, the source of Eastern Turkic features seen in Turkish mirajname texts of the Lithuanian Tatars may come from Kipchak Turkic which is the basis of the Lithuanian Tatars mother tongue that they forgot. As it is well-known, the Kipchaks have used Eastern Turkic as a written language in the middle period. The author of Kitab who replicated the mirajname text belonging to Western Turkic for the first time might have transferred the features of Eastern Turkic remained in his mind to this text without noticing.

In our opinion, more clear interpretation may be made along with other studies about the manuscripts of the Lithuanian Tatars. 


\section{Bibliography}

Akiner, Shirin 2009. Religious Language of a Belarusian Tatar Kitab. A Cultural Monument of Islam in Europe (With a Latin-Script Transliteration of the British Library Tatar Belarusian Kitab [OR13020] on CD-ROM). Mediterranean Language and Culture Monograph Series 11. Wiesbaden: Harrassowitz Verlag.

Antonowicz, Anton 1968. Biełorusskije tieksty, pisannyje arabskim pis'mom, i ich grafiko-orfograficzeskaja sistiema. Wilno: Wileński Uniwersytet Państwowy im. V. Kapsukasa.

Çimen, Sema 2010. 15. Yüzyıla Ait Anonim Bir Mírâc-nâme (Transkripsiyonlu Metin). Unpublished MA thesis. Istanbul: University of Marmara.

Develi, Hayati 1998. „Eski Türkiye Türkçesi Devresine Ait Manzum Bir Miracnâme”. İstanbul Üniversitesi Edebiyat Fakültesi Türk Dili ve Edebiyatı Dergisi 28: 81-228.

Durgut, Hüseyin 2013. „Litvanya Tatarlarına Ait El Yazmalarında Bulunan Türkçe Metinlerin Dil Özellikleri: „Miraçname “Esasında”. Türk Dünyası Araştırmaları 207: 335-344.

_ 2016. İbn Abraham Karitski Kitabı Miraçnamesi İnceleme-Metin-Dizin. Konya: Kömen Yayınları.

Miškiniené, Galina 2011. „Litvanya Tatarlarına Ait El Yazmalarında Bulunan Mi’râc-nâme”. Hacettepe Üniversitesi Türkiyat Araştırmaları Dergisi 14: 225-239.

_ 2013. „O tiekstołogii rukopisnych kitabow litowskich tatar: legienda Miradż”. Slavistica Vilnensis (Kalbotyra) 58 (2): 99-119.

— 2014a. „O kitabie Abragama Karickogo (osobiennosti jazyka i kompozicyi, tiekst pogriebalnogo obriada)". W: Nadieżda Morozowa [\&] Marina W. Czistiakowa (red.). Stawianskaja pis'miennost' Wielikogo Kniażestwa litowskogo: charaktiernyje czerty i spiecyficzeskije osobiennosti. Wilno: Instytut Języka Litewskiego.

— 2014b. „Szest' skazanij w sostawie kitabow A. Karickogo i I. Łuckiewicza (sopostawitielnyj analiz, publikacyja tiekstow)”. W: Nadieżda Morozowa [\&] Marina W. Czistiakowa (red.). Stawianskaja pis'miennost' Wielikogo kniażestwa Litowskogo: charaktiernyje czerty i spiecyficzeskije osobiennosti. Wilno: Instytut Języka Litewskiego.

2015. „Tarihî Metinlerin Çevirisinde Karşılaşılan Zorluklara Litvanya Tatarlarına Ait Eserlerden Örnekler". Türk Dünyası Kültür Araştırmaları Dergisi 1: 35-53.

Miškinienè, Galina [\&] Sigita Namavičiute [\&] Jekatierina Pokrovskaja 2005. Katałog arabskoalfawitnych rukopisiej litowskich tatar. Wilno: Wydawnictwo Uniwersytetu Wileńskiego.

Orhonlu, Cengiz 1971. „Lipkalar”. Türkiyat Mecmuası 16: 57-87. 